\title{
KEMAHIRAN PENAAKULAN SAINTIFIK MURID SEKOLAH RENDAH
}

\author{
${ }^{1}$ Suhaimi Zainol Abidin, ${ }^{2}$ Noor Shah Saad, ${ }^{3}$ Mohd Uzi Dollah, ${ }^{4}$ Qismullah Yusuf \\ ${ }^{1}$ SK Rapat Setia, 31350 Ipoh, Perak \\ 2,3,4Fakulti Pembangunan Malaysia \\ Universiti Pendidikan Sultan Idris
}

\begin{abstract}
Abstrak
Tujuan penyelidikan tinjauan ini adalah untuk menentukan tahap kemahiran penaakulan saintifik (KPS) murid-murid tahap dua sekolah rendah serta mengkaji corak kemahiran penaakulan saintifik murid melalui Ujian Penaakulan Saintifik Bilik Darjah (UPSBD). Secara spesifiknya, objektif kajian adalah menentukan tahap kemahiran penaakulan saintifik murid tahap dua, membandingkan tahap kemahiran penaakulan saintifik murid tahun lima dengan murid tahun enam, membandingkan tahap kemahiran penaakulan saintifik murid lelaki dengan murid perempuan, membandingkan tahap kemahiran penaakulan saintifik dalam kalangan murid tahap dua antara sekolah, dan menentukan corak kemahiran penaakulan saintifik murid tahap dua. Seramai 267 murid tahap dua yang terdiri daripada murid tahun lima dan tahun enam daripada lima buah sekolah dipilih sebagai sampel kajian. Instrumen yang digunakan ialah Ujian Penaakulan Saintifik Bilik Darjah yang telah diterjemahkan daripada versi asal Lawson (2000). Statistik deskriptif seperti frekuensi, peratus, min dan statistik inferensi seperti ujian-t dan ANOVA digunakan untuk menganalisis data. Hasil kajian menunjukkan tahap kemahiran penaakulan saintifik dalam kalangan murid masih berada pada tahap yang pertama dalam kemahiran penaakulan saintifik iaitu tahap operasi konkrit dengan min keseluruhannya adalah 1.0037. Tidak ada perbezaan yang signifikan antara murid tahun lima dengan murid tahun enam $(\mathrm{t}(265)=-0.996, \mathrm{p}>0.05)$. Begitu juga keputusannya bila perbandingan dibuat antara murid lelaki dengan murid perempuan $(\mathrm{t}(265)=1.116, \mathrm{p}>0.05)$. Perbandingan tahap kemahiran penaakulan saintifik antara sekolah juga tidak menunjukkan perbezaan yang signifikan $(\mathrm{F}(4,262)=1.010, \mathrm{p}>0.05)$. Corak kemahiran penaakulan saintifik tertumpu pada item satu iaitu aspek pengabdian berat dengan 23.6\%. Manakala aspek pemikiran perkadaran lanjutan langsung tidak dapat dijawab dengan betul oleh responden kajian.
\end{abstract}

\section{Kata kunci Kemahiran penaakulan saintifik, Ujian Penaakulan Bilik} Darjah Lawson.

\begin{abstract}
The purpose of this survey research is to determine the level of scientific reasoning skills among level two pupils of selected primary schools and to study the pattern of students' scientific reasoning skills through Lawson's Classroom Test of Scientific Reasoning. Specifically, the research objectives are to determine the level of scientific reasoning skills of level two students, to make comparison between year five and year six pupils towards the scientific
\end{abstract}


reasoning skills, to make comparison of the scientific reasoning skills between boys and girls, to make comparison of the scientific reasoning skills among level two pupils from a few schools, and to determine the patterns of scientific reasoning skills of the level two pupils. A total of 267 consisting of level two pupils of years five and six from five schools are selected for this study. The instrument used is the Classroom Test of Scientific Reasoning which has been translated from the original version of Lawson (2000). Descriptive statistics namely frequency, percentage, mean and inferential statistics such as t-test and ANOVA were used to analyze data. The result showed that the level of scientific reasoning skills among these pupils are still at the lowest level of the scientific reasoning skills, concrete operations with the overall mean 1.0037. There is no significant difference between years five and six pupils $(\mathrm{t}(265)=-0.996, \mathrm{p}>0.05)$. Similar result which also shown no significant difference is obtained between the boys and girls $(\mathrm{t}(265)=1.116, \mathrm{p}>0.05)$. It is also found that the same result is collected which showed no significant difference from among schools involved $(\mathrm{F}(4,262)=1.010, \mathrm{p}>0.05)$. The pattern of the scientific reasoning skills is solely found on item one, where the conservation of weight is $23.6 \%$. While the proportional reasoning could not be answered correctly by the respondents.

Keywords Scientific reasoning skill, Lawson Classroom Test for Formal Reasoning.

\section{PENGENALAN}

Malaysia berhasrat untuk menjadi sebuah negara maju menjelang terbitnya fajar pertama pada tahun 2020. Selaras dengan hasrat kerajaan tersebut maka Kementerian Pendidikan Malaysia (KPM) telah menentukan peratusan pelajar dalam bidang sains dan teknikal sebanyak $60 \%$ dan dalam bidang sastera pula ialah $40 \%$ (Kementerian Pendidikan Malaysia [KPM], 2012). Mulai tahun 2010 Kementerian Pendidikan Malaysia telah memperkenalkan aspek penaakulan saintifik dalam bentuk kemahiran proses sains asas dan bersepadu serta pemikiran saintifik di sekolah-sekolah kebangsaan. Pelaksanaan Kurikulum Standard Sekolah Rendah (KSSR) telah menerapkan kemahiran menaakul di samping kemahiran asas yang sedia ada iaitu membaca, menulis dan mengira. Kemahiran menaakul penting untuk melahirkan insan yang berfikiran kreatif, kritis dan inovatif dan mampu berdaya saing di persada dunia di zaman yang semakin mencabar kelak.

Dunia hari ini menyaksikan bagaimana ilmu dimartabatkan sebagai kuasa ekonomi dan sumber kekayaan sesebuah negara ekoran kesediaan masyarakat antarabangsa menerima persejagatan (globalisasi) sebagai dasar kemajuan dalam gelombang ketiga, abad 21 (Toffler, 1991). Cabaran dan saingan dalam ekonomi baru dan persejagatan telah menuntut Malaysia untuk melaksanakan pembaharuan bagi mencapai wawasan untuk menjadikan negara ini maju menjelang 2020 (Mahathir, 1991).

Sendi kepada persaingan ekonomi baru ialah kecemerlangan dan kebijaksanaan. Oleh itu, sistem pendidikan perlu diolah untuk melahirkan modal insan minda kelas pertama yang bijak, kritis, kreatif dan berkemahiran. Sebelum ini guru mengajar dengan hanya memberi tumpuan kepada apa yang perlu difikirkan dan apa yang sepatutnya dipelajari oleh murid-muridnya semata-mata namun kini guru perlu 
melakukan perubahan dalam komponen pengajaran dan pembelajaran matematik di sekolah dengan mengembangkan kemahiran bagaimana untuk belajar dan bagaimana untuk berfikir sejajar dengan amalan pengajaran dan pembelajaran abad ke-21 yang sedang hangat diperkatakan kini.

Oleh itu modal insan yang dilahirkan bukan semata-mata bijaksana dan mudah menyesuaikan diri, tidak bersikap mementingkan diri sendiri malahan selesa dan mudah bekerja dengan pelbagai pihak tanpa sempadan agama dan bangsa untuk mencapai aspirasi negara.

\section{PERNYATAAN MASALAH}

Bahagian Pembangunan Kurikulum (BPK) (2012), menyatakan kemahiran menaakul ialah penggunaan pemikiran dan pertimbangan logik untuk memahami sesuatu situasi atau idea. Sesuatu tindak balas secara sedar yang memerlukan manusia membuat inferensi daripada pemerhatian, fakta, atau andaian diklasifikasikan sebagai menaakul. Penaakulan terbahagi kepada dua iaitu penaakulan deduktif dan penaakulan induktif. Satu siri pemerhatian atau proposisi yang membentuk satu kesimpulan adalah hasil daripada kedua-dua jenis penaakulan ini. Pengalaman yang berkaitan apabila digabungkan dengan penaakulan dikatakan dapat meningkatkan pengekalan ingatan, kreativiti dan proses menyelesaikan masalah. Seseorang yang dapat berfikir secara kreatif adalah merupakan seorang penyelesai masalah yang terbaik. Disiplin sains dan matematik berkait rapat dengan kemahiran menaakul.

Pelajar-pelajar pula didapati belum menguasai KPS (Omar et al., 1999). Cara pelajar di ajar dan belajar pada masa kini, menyebabkan pengetahuan yang dikuasai tidak kekal dan pelajar gagal menggunakan prinsip dan proses saintifik untuk membuat keputusan dalam kehidupan mereka (Abu Bakar, 1995; Kelly, G. J., Carlsen, W. S., Cunningham, C. M., 1993; dan National Academy of Science, 1996). Walaupun amalan pengajaran dan pembelajaran yang menekankan hafalan dan ingatan kembali serta berpusatkan guru dipatuhi sepenuhnya oleh para guru ketika mengajar matematik namun peratusan pelajar yang cemerlang dalam matematik masih berterusan rendah malahan kemahiran penaakulan saintifik tidak dapat dikuasai oleh ramai pelajar menyebabkan bilangan pelajar gagal berterusan tinggi (Mohamad Fadzil, 2008).

Kedudukan Malaysia dalam TIMMS dan PISA telah merosot dari semasa ke semasa dan kini Malaysia berada di kelompok tiga terbawah kerana soalan yang disediakan melibatkan soalan penyelesaian masalah Kemahiran Berfikir Aras Tinggi (KBAT). Ini adalah berdasarkan laporan yang telah dikeluarkan oleh Lembaga Peperiksaan Malaysia (LPM). Oleh yang demikian pihak Kementerian Pendidikan Malaysia (KPM) dan Lembaga Peperiksaan Malaysia (LPM) telah bersetuju untuk menyedia dan menyelitkan soalan-soalan berunsurkan KBAT dalam peperiksaan awam. Soalan KBAT telah mula diperkenalkan dalam peperiksaan awam di peringkat Ujian Penilaian Sekolah Rendah (UPSR), Pentaksiran Tingkatan Tiga (PT3), Sijil Pelajaran Malaysia (SPM) dan Sijil Tinggi Persekolahan Malaysia (STPM) mulai 2013 (KPM, 2012). Berdasarkan Pelan Pembangunan Pendidikan Malaysia (PPPM) 2013-2025, Menteri Pendidikan sangat berharap agar mutu pencapaian pelajar Malaysia akan meningkat dalam ujian antarabangsa TIMSS dan PISA bagi membolehkan Malaysia berada di kelompok tiga teratas dalam masa terdekat. Pelbagai usaha dan program gerak gempur sedang giat dirancang dan dilaksanakan bagi mencapai sasaran tersebut 


\section{OBJEKTIF KAJIAN}

Objektif kajian ini adalah untuk :

i. Menentukan tahap kemahiran penaakulan saintifik murid tahap dua.

ii. Membandingkan tahap kemahiran penaakulan saintifik murid tahun lima dengan murid tahun enam.

iii. Membandingkan tahap kemahiran penaakulan saintifik murid lelaki dengan murid perempuan.

iv. Membandingkan tahap kemahiran penaakulan saintifik di kalangan murid tahap dua antara sekolah.

v. Menentukan corak kemahiran penaakulan saintifik (KPS) murid tahap dua.

\section{PERSOALAN KAJIAN}

Terdapat lima persoalan kajian yang ingin dijawab dalam kajian tinjauan ini. Persoalanpersoalan tersebut ialah :

i. Apakah tahap Kemahiran Penaakulan Saintifik murid tahap dua?

ii. Adakah terdapat perbezaan yang signifikan min skor tahap kemahiran penaakulan saintifik antara murid tahun lima dengan murid tahun enam?

iii. Adakah terdapat perbezaan yang signifikan min skor tahap kemahiran penaakulan saintifik antara murid lelaki dengan murid perempuan?

iv. Adakah terdapat perbezaan yang signifikan min skor tahap kemahiran penaakulan saintifik dalam kalangan murid tahap dua antara sekolah-sekolah terlibat?

v. Apakah corak kemahiran penaakulan saintifik (KPS) murid tahap dua?

\section{TINJAUAN LITERATUR}

Tahap operasi formal adalah penentu kemahiran menaakul secara saintifik yang baik. Lawson (1982) menyatakan wujudnya hubungan yang kuat antara pencapaian pelajar pada tahap operasi formal dengan kemampuan menaakul pelajar. Pemikiran Hipotetikaldeduktif (HD) mengkelaskan murid yang berkebolehan menguasai kemahiran pemikiran perkadaran dan pemikiran kebarangkalian, pemikiran mengenalpasti dan mengawal pemboleh ubah, kebolehan melakukan pemikiran pergabungan sewaktu menyelesaikan masalah dalam tahap operasi formal dalam KPS (Lawson, 1995). Pada tahap operasi formal, murid perlu menguasai dalam kemahiran berfikir yang memerlukan pemikiran peringkat tinggi menurut Piaget dan Inhender (1958).

Piaget (1896-1980) telah menjelaskan tentang kaedah manusia mempersepsi ilmu dan membina hipotesis. Beliau juga menjelaskan bagaimana minda manusia membentuk skemata dan melaksanakan proses akomodasi dan asimilasi dalam membina ilmu. Piaget mengenalpasti 4 faktor yang saling berkait yang boleh mempengaruhi proses pemikiran individu: i) Kematangan biologi, proses pemikiran yang dipengaruhi oleh faktor baka atau genetik; ii) Interaksi individu dengan persekitaran, salah satu proses yang dilalui oleh manusia untuk memahami perkara-perkara yang berlaku; iii) Pengalaman sosial, perkembangan kognitif juga dipengaruhi oleh pergaulan individu dengan orang-orang di sekelilingnya; dan iv) Keseimbangan, proses keseimbangan adalah merupakan salah satu cara yang digunakan oleh individu untuk mengadaptasi dengan situasi yang baru dialami.

Nor'Ain et al., (2011) dalam kajian ke atas pelajar Institusi Pengajian Tinggi Awam (IPTA) Malaysia secara keseluruhannya mendapati hanya 6.2\% daripada 975 
pelajar IPTA Malaysia mencapai tahap 3 iaitu operasi formal, 30.7\% mencapai tahap (operasi transisi) dan selebihnya sebanyak 63.2\% pelajar berada di tahap 1 (operasi konkrit). Berdasarkan hasil dapatan kajian tersebut didapati ada universiti yang tiada langsung pelajarnya yang berjaya mencapai tahap yang ketiga iaitu peringkat operasi formal.

Kajian yang dilakukan oleh Syamsina (2011) ke atas guru-guru matematik dan sains menunjukkan bahawa tahap kemahiran penaakulan saintifik dalam kalangan guru-guru juga masih rendah. Bagi guru matematik, hanya $1.4 \%$ berjaya mencapai tahap 3 (operasi formal) dan $11.4 \%$ berada pada tahap 2 (operasi transisi) manakala sebilangan besar iaitu $87.1 \%$ masih berada di tahap terendah (operasi konkrit). Bagi guru sains pula tidak ada seorang pun yang berjaya mencapai tahap operasi formal, $18 \%$ mencapai operasi transisi dan $82 \%$ berada di operasi konkrit.

Dapatan kajian Suzana (2014) menunjukkan bahawa tahap kemahiran penaakulan saintifik dalam kalangan kebanyakan pelajar masih berada pada tahap pertama kemahiran penaakulan saintifik iaitu operasi konkrit dengan min skor tahap KPS adalah 1.76. Kajian ini dijalankan ke atas 351 orang pelajar tingkatan empat (15 hingga 16 tahun) di Pulau Pinang.

Amalina et al., (2012) dalam kajiannya mendapati 73.3\% pelajar mencapai tahap 1 dengan min 2.63, 25\% pelajar memperoleh KPS tahap 2 dengan min 5.63 dan hanya $1.7 \%$ sahaja pelajar mencapai tahap 3 dengan minnya 9.00. Hasil dapatan memberi indikasi bahawa pelajar di UPSI memiliki tahap KPS pada tahap konkrit.

\section{METODOLOGI}

Rekabentuk kajian ini adalah kajian penyelidikan tinjauan dengan pendekatan kuantitatif. Kajian ini menggunakan Ujian Penaakulan Saintifik Bilik Darjah yang diterjemahkan daripada versi asal Lawson (1978) yang telah disemak Lawson (2000) untuk menentukan tahap kemahiran penaakulan saintifik (KPS) murid tahun lima dan tahun enam di beberapa buah sekolah di Daerah Kinta Utara.

Instrumen ini terdiri daripada 12 soalan berpasangan (jumlah keseluruhan soalan adalah 24) yang direkabentuk untuk menilai kebolehan penaakulan murid. Ujian ini adalah ujian berformat dua peringkat dengan aneka pilihan. Murid perlu memilih penjelasan yang bersesuaian dengan pilihan jawapan yang telah dibuat sebelum ini. Responden hanya akan diberikan skor sekiranya berjaya menjawab dengan betul keduadua soalan dalam setiap pasangan tersebut. Oleh yang demikian, skor tertinggi yang dapat dicapai oleh responden adalah 12 skor. Jadual 1 menunjukkan aspek kemahiran penaakulan saintifik yang terlibat dalam item-item UPSBD.

Jadual 1 Aspek kemahiran penaakulan saintifik yang dinilai dalam UPSBD

\begin{tabular}{ll}
\hline Aspek penaakulan yang dinilai & Nombor item \\
\hline Pengabdian berat & 1,2 \\
\hline Pengabdian isipadu tersesar (pemindahan) & 3,4 \\
\hline Pemikiran perkadaran & 5,6 \\
\hline Pemikiran perkadaran lanjutan & 7,8 \\
\hline Mengenal pasti dan mengawal pemboleh ubah & 9,10 \\
\hline
\end{tabular}




\begin{tabular}{ll}
\hline $\begin{array}{l}\text { Mengenal pasti dan mengawal pemboleh ubah dan } \\
\text { Pemikiran kebarangkalian }\end{array}$ & 11,12 \\
\hline Pemikiran kebarangkalian & 13,14 \\
\hline Pemikiran kebarangkalian lanjutan & 15,16 \\
\hline Pemikiran tentang kolerasi/saling hubungan & 17,18 \\
\hline Pemikiran tentang hipotetikal deduktif/ kombinatorial & 19,20 \\
\hline Penaakulan hipotetikal-deduktif/kombinatorial & 21,22 \\
\hline
\end{tabular}

Murid yang mendapat skor 0-4 mata mencapai tahap pertama iaitu peringkat operasi konkrit. Murid yang mendapat skor 5-8 pula mencapai tahap kedua iaitu tahap operasi transisi manakala murid yang berjaya mendapat skor 9-12 mata akan mencapai tahap tertinggi iaitu peringkat operasi formal. Skema pengelasan skor UPSBD adalah seperti yang ditunjukkan dalam Jadual 2 .

Jadual 2 Skema pengelasan peringkat kognitif Piaget berdasarkan skor UPSBD

\begin{tabular}{cc}
\hline Skor UPSBD & Tahap Kemahiran Penaakulan \\
\hline $0-4$ & Operasi Konkrit \\
\hline $5-8$ & Operasi Transisi \\
\hline $9-12$ & Operasi Formal \\
\hline
\end{tabular}

\section{DAPATAN KAJIAN}

Jadual 3 menunjukkan taburan responden yang dikaji daripada lima buah sekolah mengikut jantina dan kelas pembelajaran. Bilangan murid tahun lima dengan murid tahun enam hampir seimbang di mana seramai 133 orang $(49.8 \%)$ adalah murid tahun lima dan bilangan murid tahun enam hanya lebih seorang daripada bilangan murid tahun lima iaitu seramai 134 orang. Taburan berdasarkan jantina pula mendapati bilangan murid perempuan seramai 148 orang merangkumi 55.4\% manakala murid lelaki hanya mewakili $44.6 \%$ iaitu seramai 119 orang.

Jadual 3 Taburan responden kajian mengikut jantina

\begin{tabular}{cccccc}
\hline \multirow{2}{*}{5} & 5 & & \multicolumn{2}{c}{ Tahun } & \multirow{2}{*}{ Jumlah } \\
\cline { 3 - 5 } & \multirow{3}{*}{ Lelaki } & Bil. & 56 & 63 & \\
\hline \multirow{3}{*}{ Jantina } & & $\%$ & $21.0 \%$ & $23.6 \%$ & $419.6 \%$ \\
& \multirow{2}{*}{ Perempuan } & Bil. & 77 & 71 & 148 \\
& & $\%$ & $28.8 \%$ & $26.6 \%$ & $55.4 \%$ \\
\hline \multirow{3}{*}{ Jumlah } & & Bil. & 133 & 134 & 267 \\
& & $\%$ & $49.8 \%$ & $50.2 \%$ & $100.0 \%$ \\
\hline
\end{tabular}

Secara keseluruhannya bilangan responden yang terlibat dalan kajian ini adalah seramai 267 orang murid. Jadual 4 menunjukkan taburan responden kajian. 
Jadual 4 Taburan responden kajian

\begin{tabular}{ccccccc}
\hline & \multicolumn{2}{c}{ Tahun Lima } & \multicolumn{2}{c}{ Tahun Enam } & \multicolumn{2}{c}{ Jumlah } \\
\cline { 2 - 7 } Sekolah & Bil & $\%$ & Bil & $\%$ & Bil & $\%$ \\
& & & & & & \\
\hline SKPPH & 28 & 10.5 & 25 & 9.4 & 53 & 19.9 \\
SKRS & 27 & 10.1 & 27 & 10.1 & 54 & 20.2 \\
SKKPP & 25 & 9.4 & 25 & 9.7 & 51 & 19.1 \\
SKSR & 28 & 10.5 & 29 & 10.9 & 57 & 21.3 \\
SKHM & 25 & 9.4 & 27 & 10.1 & 52 & 19.5 \\
\hline Jumlah & 133 & 49.8 & 134 & 50.2 & 267 & 100 \\
\hline
\end{tabular}

Berdasarkan dapatan kajian, secara keseluruhannya didapati hanya seorang sahaja murid tahap dua $(0.4 \%)$ daripada 267 responden yang dikaji berjaya mencapai tahap KPS yang kedua iaitu peringkat operasi transisi. Responden yang mencapai tahap operasi konkrit mewakili sebahagian besar murid tahap dua dengan $99.6 \%$. Tiada seorang pun murid yang berjaya mencapai tahap KPS yang ketiga iaitu operasi formal. Jadual 5 menunjukkan tahap KPS yang dicapai oleh murid tahap dua.

Jadual 5 Jadual Tahap KPS murid tahap dua

\begin{tabular}{ccc}
\hline Tahap KPS & Bil & $\%$ \\
\hline Operasi Konkrit & 266 & 99.6 \\
Operasi Transisi & 1 & 0.4 \\
Operasi Formal & 0 & 0 \\
\hline Jumlah & 267 & 100 \\
\hline
\end{tabular}

Keseluruhan murid tahap dua bagi empat buah sekolah yang lain hanya mencapai tahap KPS yang pertama iaitu tahap operasi konkrit. Seorang murid dari SKPPH yang terdiri daripada 53 berjaya mencapai tahap operasi transisi $(0.4 \%)$. Tidak ada seorang pun responden dari semua sekolah yang dikaji mencapai tahap operasi formal. Jadual 6 menunjukkan tahap KPS yang dicapai oleh murid tahap dua mengikut sekolah.

Jadual 6 Tahap KPS yang dicapai oleh murid tahap dua mengikut sekolah

\begin{tabular}{|c|c|c|c|c|}
\hline \multirow[b]{2}{*}{ Sekolah } & \multirow[b]{2}{*}{$\mathrm{N}$} & \multicolumn{3}{|c|}{ Tahap KPS } \\
\hline & & Operasi Konkrit & Operasi Transisi & $\begin{array}{l}\text { Operasi } \\
\text { Formal }\end{array}$ \\
\hline SKPPH & 53 & $52(19.5 \%)$ & $1(0.4 \%)$ & 0 \\
\hline SKRS & 54 & $54(20.2 \%)$ & 0 & 0 \\
\hline SKKPP & 51 & $51(19.1 \%)$ & 0 & 0 \\
\hline SKSR & 57 & $57(21.3 \%)$ & 0 & 0 \\
\hline SKHM & 52 & $52(19.5 \%)$ & 0 & 0 \\
\hline JUMLAH & 267 & $266(99.6 \%)$ & $1(0.4 \%)$ & 0 \\
\hline
\end{tabular}


Jadual 7 memperincikan tahap KPS yang dicapai oleh murid tahun lima dan tahun enam di semua sekolah yang dikaji. Melalui perbandingan tahap KPS mengikut tahun, semua murid tahun lima seramai 133 orang berada di tahap KPS yang pertama (operasi konkrit). Manakala bagi tahun enam pula terdapat seorang murid $(0.04 \%)$ daripada 134 orang murid telah berjaya mencapai tahap operasi transisi.

Jadual 7 Tahap KPS yang dicapai oleh murid tahun lima dan tahun enam

\begin{tabular}{|c|c|c|c|c|}
\hline \multirow{2}{*}{ Tahap KPS } & \multicolumn{2}{|c|}{ Tahun } & \multirow{2}{*}{ Perbezaan (\%) } & \multirow{2}{*}{$\begin{array}{c}\text { Jumlah } \\
\text { Keseluruhan }\end{array}$} \\
\hline & Lima & Enam & & \\
\hline Operasi Konkrit & $133(49.8 \%)$ & $133(49.8 \%)$ & 0 & $266(99.6 \%)$ \\
\hline Operasi Transisi & 0 & $1(0.4 \%)$ & 0.4 & $1(0.4 \%)$ \\
\hline Operasi Formal & 0 & 0 & 0 & 0 \\
\hline Jumlah & 133 & 134 & & $267(100 \%)$ \\
\hline
\end{tabular}

Jadual 8 menunjukkan perbandingan keseluruhan tahap KPS antara murid tahun lima dan murid tahun enam sekolah terlibat. Min skor tahap KPS bagi murid tahun lima ialah 1.00, manakala bagi murid tahun enam ialah 1.0075. Analisis daripada Jadual 8 menunjukkan wujud perbezaan min yang signifikan $(\mathrm{t}(265)=-0.996, \mathrm{p}>0.05)$. Oleh itu $\mathrm{H}_{0} 1$ diterima. Ini menunjukkan tidak terdapat perbezaan min skor tahap KPS antara murid tahun lima dengan murid tahun enam bagi sekolah yang terlibat.

Jadual 8 Perbandingan keseluruhan tahap KPS murid tahun lima dan tahun enam

\begin{tabular}{ccccccccc} 
Tahun & $\mathrm{N}$ & Min & $\begin{array}{c}\text { Sisihan } \\
\text { Piawai }\end{array}$ & $\mathrm{F}$ & Sig. & $\mathrm{t}$ & $\mathrm{df}$ & $\begin{array}{c}\text { Sig. } \\
\text { (2-tailed) }\end{array}$ \\
\cline { 1 - 2 } & 133 & 1.00 & 0.000 & & & & & \\
Lima & 134 & 1.0075 & 0.086 & 4.030 & 0.046 & -0.996 & 265 & 0.32 \\
\hline
\end{tabular}

Tahap KPS bagi semua murid tahap dua yang dikaji berdasarkan jantina ditunjukkan dalam Jadual 9. Melalui perbandingan tahap KPS mengikut jantina, didapati semua murid perempuan seramai 148 orang mewakili 55.4 peratus daripada keseluruhan responden yang dikaji hanya berjaya mencapai tahap KPS yang pertama sahaja iaitu operasi konkrit. Namun begitu, berlainan pula dengan pencapaian murid lelaki di mana ada seorang murid lelaki (0.04\%) yang telah berjaya mencapai tahap KPS yang kedua iaitu operasi transisi daripada seramai 119 orang murid lelaki.

Jadual 9 Tahap KPS bagi keseluruhan murid tahap dua mengikut jantina

\begin{tabular}{ccccc}
\hline Tahap KPS & \multicolumn{2}{c}{ Jantina } & Perbezaan (\%) & Jumlah \\
& Lelaki & Perempuan & & Keseluruhan \\
\hline Operasi Konkrit & $118(44.2 \%)$ & $148(55.4 \%)$ & 0 & $266(99.6 \%)$ \\
Operasi Transisi & $1(0.4 \%)$ & 0 & 0.4 & $1(0.4 \%)$ \\
Operasi Formal & 0 & 0 & 0 & 0 \\
\hline Jumlah & 119 & 148 & & $267(100 \%)$ \\
\hline
\end{tabular}


Jadual 10 menunjukkan perbandingan keseluruhan tahap KPS antara murid lelaki dan murid perempuan sekolah terlibat. Min skor tahap KPS bagi murid lelaki ialah 1.0084, manakala bagi murid perempuan ialah 1.00. Analisis daripada Jadual 10 menunjukkan tidak wujud perbezaan min yang signifikan $(\mathrm{t}(265)=1.116$, $\mathrm{p}>0.05)$. Oleh itu $\mathrm{H}_{\mathrm{o}} 2$ diterima. Ini menunjukkan tidak terdapat perbezaan yang signifikan dalam min skor tahap KPS antara murid lelaki dengan murid perempuan bagi sekolah-sekolah yang terlibat.

Jadual 10 Perbandingan keseluruhan tahap KPS murid lelaki dan perempuan

\begin{tabular}{|c|c|c|c|c|c|c|c|c|}
\hline Jantina & $\mathrm{N}$ & Min & $\begin{array}{l}\text { Sisihan } \\
\text { Piawai }\end{array}$ & $\mathrm{F}$ & Sig. & $\mathrm{t}$ & Df & $\begin{array}{c}\text { Sig. } \\
\text { (2-tailed) }\end{array}$ \\
\hline Lelaki & 119 & 1.0084 & 0.092 & \multirow{2}{*}{5.065} & \multirow{2}{*}{0.025} & \multirow{2}{*}{1.116} & \multirow{2}{*}{265} & \multirow{2}{*}{0.266} \\
\hline Perempuan & 148 & 1.00 & 0.000 & & & & & \\
\hline
\end{tabular}

Min skor tahap KPS bagi semua sekolah adalah sama (1.00) kecuali SKPPH. Keadaan ini berlaku kerana semua murid bagi keempat-empat buah sekolah itu hanya mencapai tahap operasi konkrit. Nilai min dan sisihan piawai skor tahap KPS bagi setiap sekolah ditunjukkan dalam Jadual 11.

Jadual 11 Nilai min skor tahap KPS

\begin{tabular}{cccc}
\hline Sekolah & $\mathrm{N}$ & Min & Sisihan Piawai \\
\hline SKPPH & 53 & 1.0189 & .13736 \\
SKRS & 54 & 1.0000 & .00000 \\
SKKPP & 51 & 1.0000 & .00000 \\
SKSR & 57 & 1.0000 & .00000 \\
SKHM & 52 & 1.0000 & .00000 \\
\hline Jumlah & 267 & 1.0037 & .06120 \\
\hline
\end{tabular}

Untuk mencari perbezaan min skor tahap kemahiran penaakulan saintifik (KPS) antara sekolah, rujuk kepada Jadual 12. Analisis menggunakan ANOVA bagi melihat perbezaan min skor tahap KPS antara lima buah yang sekolah terlibat. Lihat pada nilai F (test statistic) iaitu 1.010 dan nilai Sig. (P-Value) pada 0.403 $(\mathrm{p}>0.05)$, dalam kes ini kita menerima hypotesis null, serta membuat kesimpulan bahawa tidak terdapat perbezaan yang signifikan di dalam min skor tahap KPS antara sekolah-sekolah yang terlibat.

Jadual 12 Perbandingan min skor tahap KPS antara sekolah

\begin{tabular}{llclll}
\hline Tahap KPS & SS & df & MS & F & Sig. \\
\hline Antara Sekolah & .015 & 4 & .004 & 1.010 & .403 \\
Dalam Sekolah & .981 & 262 & .004 & & \\
\hline Jumlah & .996 & 266 & & & \\
\hline
\end{tabular}

Berdasarkan maklumat daripada Jadual 13 dapat dibuat kesimpulan bahawa tidak terdapat perbezaan yang signifikan min skor tahap KPS antara sekolah-sekolah yang terlibat. Semua responden dari semua sekolah hanya berada 
di tahap yang pertama dalam kemahiran penaakulan saintifik iaitu operasi konkrit kecuali seorang responden dari SKPPH yang berjaya mencapai tahap operasi transisi.

Jadual 13 Perbezaan min skor tahap KPS antara sekolah

\begin{tabular}{llccc}
\hline (I) Sekolah & (J) Sekolah & $\begin{array}{c}\text { Perbezaan } \\
\text { Min (I-J) }\end{array}$ & Z & Sig. \\
\hline \multirow{3}{*}{ SKPPH } & SKRS & .01887 & .01183 & .502 \\
& SKKPP & .01887 & .01200 & .517 \\
& SKSR & .01887 & .01168 & .489 \\
& SKHM & .01887 & .01194 & .512 \\
\hline \multirow{3}{*}{ SKRS } & SKPPH & -.01887 & .01183 & .502 \\
& SKKPP & .00000 & .01195 & 1.000 \\
& SKSR & .00000 & .01162 & 1.000 \\
& SKHM & .00000 & .01189 & 1.000 \\
\hline \multirow{6}{*}{ SKKPP } & SKPPH & -.01887 & .01200 & .517 \\
& SKRS & .00000 & .01195 & 1.000 \\
& SKSR & .00000 & .01180 & 1.000 \\
& SKHM & .00000 & .01206 & 1.000 \\
\hline \multirow{6}{*}{ SKSR } & SKPPH & -.01887 & .01168 & .489 \\
& SKRS & .00000 & .01162 & 1.000 \\
& SKKPP & .00000 & .01180 & 1.000 \\
& SKHM & .00000 & .01174 & 1.000 \\
\hline \multirow{6}{*}{ SKHM } & SKPPH & -.01887 & .01194 & .512 \\
& SKRS & .00000 & .01189 & 1.000 \\
& SKKPP & .00000 & .01206 & 1.000 \\
& SKSR & .00000 & .01174 & 1.000 \\
\hline
\end{tabular}

Melalui perbandingan nilai sig. min skor tahap KPS antara kumpulan didapati nilai minimum bagi p ialah 0.489 dan nilai maksimum bagi p ialah 1.00 . Oleh yang demikian nilai sig. bagi perbandingan setiap sekolah adalah lebih besar daripada nilai alpha (0.05). Oleh yang demikian $\mathrm{H}_{0} 3$ diterima. Kesimpulannya dapatlah dirumuskan bahawa tidak terdapat perbezaan yang signifikan min skor tahap KPS dalam kalangan murid tahap dua antara sekolah-sekolah terlibat.

Jadual 14 menghuraikan dengan terperinci corak kemahiran penaakulan saintifik berdasarkan bilangan murid tahap dua yang menjawab dengan betul bagi setiap aspek kemahiran penaakulan saintifik (KPS) yang dinilai berdasarkan Ujian Penaakulan Saintifik Bilik Darjah (Lawson, 2000) yang telah diterjemahkan ke dalam Bahasa Melayu.

Item KPS yang pertama iaitu pengabdian berat merupakan aspek yang paling mudah atau paling banyak dijawab dengan betul oleh murid-murid tahap dua yang dinilai. Seramai 63 orang murid $(23.6 \%)$ dapat menjawab item ini dengan betul. Ini diikuti dengan aspek pemikiran tentang kolerasi/saling hubungan (item 10), di mana seramai 43 orang murid (16.1\%) berjaya menjawab 
dengan betul. Seterusnya, seramai 41 orang $(15.36 \%)$ dapat menjawab dengan betul item 12 yang melibatkan aspek pemikiran tentang hipotetikal deduktif/ kombinatorial.

Jadual 14 Corak aspek kemahiran penaakulan saintifik

\begin{tabular}{|c|c|c|c|c|}
\hline Item & Aspek kemahiran penaakulan saintifik & $\begin{array}{l}\text { Bil. } \\
\text { Betul }\end{array}$ & $\%$ & Min \\
\hline 1 & Pengabdian berat & 63 & 23.60 & 0.2360 \\
\hline 2 & Pengabdian isipadu tersesar (pemindahan) & 21 & 7.87 & 0.0787 \\
\hline 3 & Pemikiran perkadaran & 10 & 3.75 & 0.0375 \\
\hline 4 & Pemikiran perkadaran lanjutan & 0 & 0.00 & 0.0000 \\
\hline 5 & Mengenal pasti dan mengawal pemboleh ubah & 14 & 5.24 & 0.0524 \\
\hline 6 & $\begin{array}{l}\text { Mengenal pasti dan mengawal pemboleh ubah } \\
\text { dan pemikiran kebarangkalian }\end{array}$ & 5 & 1.87 & 0.0187 \\
\hline 7 & $\begin{array}{l}\text { Mengenal pasti dan mengawal pemboleh ubah } \\
\text { dan pemikiran kebarangkalian }\end{array}$ & 12 & 4.49 & 0.0449 \\
\hline 8 & Pemikiran kebarangkalian & 8 & 3.00 & 0.0300 \\
\hline 9 & Pemikiran kebarangkalian lanjutan & 27 & 10.11 & 0.1011 \\
\hline 10 & Pemikiran tentang kolerasi/saling hubungan & 43 & 16.10 & 0.1610 \\
\hline 11 & $\begin{array}{l}\text { Pemikiran tentang hipotetikal deduktif/ } \\
\text { kombinatorial }\end{array}$ & 13 & 4.87 & 0.0487 \\
\hline 12 & Penaakulan hipotetikal-deduktif/kombinatorial & 41 & 15.36 & 0.1536 \\
\hline
\end{tabular}

Rajah 1 menunjukkan taburan pilihan jawapan betul yang dipilih oleh murid dalam bentuk graf bar. Lapan item (aspek KPS) mendapat kurang daripada 10\% bilangan murid yang dapat menjawab dengan betul. Item KPS yang paling sukar untuk dijawab dengan betul aspek pemikiran perkadaran lanjutan, di mana tidak ada seorang pun dapat menjawab dengan betul soalan ini.

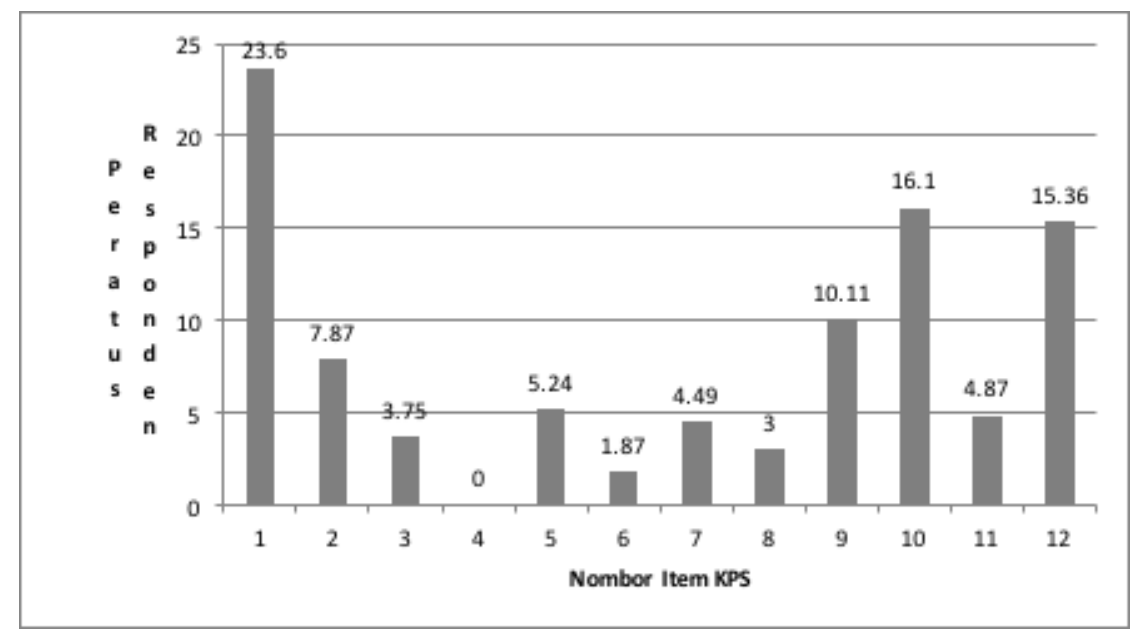

Rajah 1 Corak kemahiran penaakulan saintifik 
Rajah 2 menunjukkan jumlah kemahiran penaakulan saintifik yang dapat dikuasai oleh murid tahap dua yang dikaji. Berdasarkan dapatan kajian didapati bilangan murid yang tidak dapat memperoleh sebarang mata adalah seramai 97 orang yang mewakili $36.3 \%$. Manakala peratusan tertinggi adalah bilangan murid yang mendapat 1 mata iaitu sebanayak 38.2\% yang mewakili 102 orang. Bilangan murid yang mendapat 2 mata adalah seramai 50 orang dan yang mendapat 3 mata pula semakin berkurang menjadi 16 orang sahaja dengan mewakili $6 \%$ daripada keseluruhan murid (267 orang). Hanya seorang murid $(0.4 \%)$ sahaja yang berjaya mendapat skor 4 dan 6 mata.

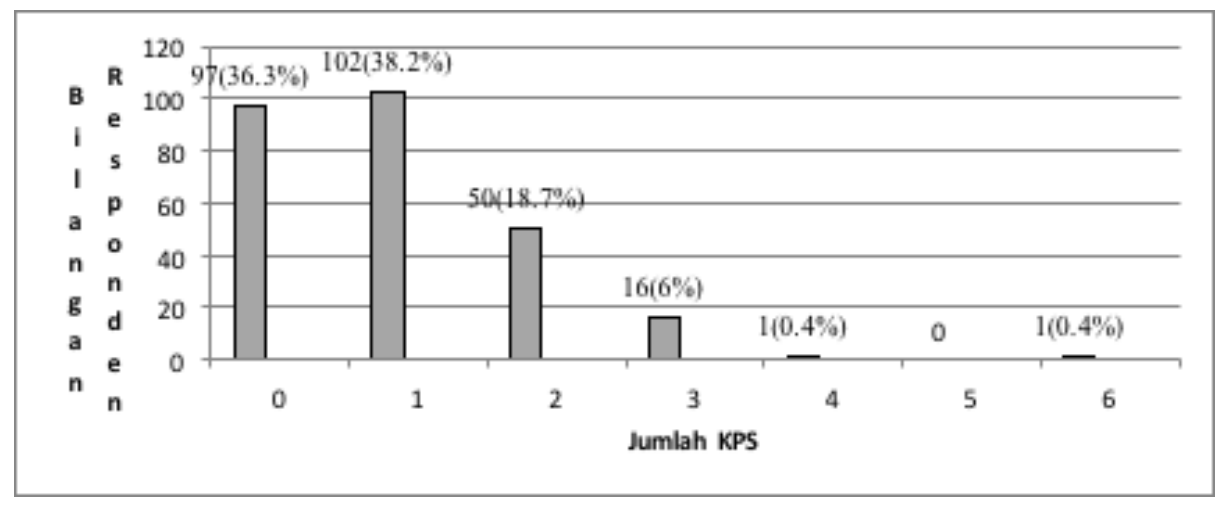

Rajah 2 Kemahiran penaakulan saintifik yang dikuasai murid tahap dua

\section{PERBINCANGAN DAN KESIMPULAN}

Berdasarkan analisis data dinyatakan bahawa seramai 266 orang murid tahap dua $(99.6 \%)$ berada pada tahap yang paling rendah iaitu operasi konkrit. Hanya seorang sahaja murid tahap dua yang berjaya melepasi peringkat operasi transisi. Semua sekolah yang dikaji menunjukkan semua murid tidak berjaya mencapai tahap KPS yang tertinggi iaitu peringkat operasi formal.

Dapatan kajian ini dari segi corak kemahiran penaakulan saintifik pula berdasarkan pola pilihan jawapan yang betul oleh responden. Hasilnya, di dapati ramai murid dapat menjawab dengan betul dalam kemahiran penaakulan saintifik aspek pengabdian berat (aspek 1) iaitu 63 orang (23.6\%) berbanding dengan aspek-aspek penaakulan yang lain. Manakala tidak ada seorang pun responden berjaya menjawab dengan betul aspek KPS yang keempat yang melibatkan aspek pemikiran perkadaran lanjutan. Hanya 5 orang murid (1.87\%) yang berjaya menjawab dengan betul aspek mengenal pasti dan mengawal pemboleh ubah dan pemikiran kebarangkalian (aspek 6). Aspek-aspek lain yang paling kurang mendapat pilihan jawapan betul adalah aspek pengabdian isi padu tersesar (pemindahan), pemikiran perkadaran, mengenal pasti dan mengawal pemboleh ubah, pemikiran kebarangkalian, dan pemikiran tentang hipotetikal-deduktif/kombinatorial. Peratusan murid yang menjawab dengan betul aspek-aspek ini tidak melebihi $8 \%$ daripada keseluruhan murid yang dikaji.

Pengajaran sains berasaskan eksperimen dan penemuan inkuiri akan menggalakkan kebolehan penaakulan saintifik berbanding pengajaran secara fakta dan bukan siasatan, Zimmerman (2007). Kemahiran inkuiri adalah penting dalam meningkatkan kemahiran menaakul secara saintifik individu. Murid seharusnya mempunyai kemahiran inkuiri yang baik bagi membolehkan mereka mencapai 
tahap operasi formal, Zuzovky dan Tamir (1989). Ini menyokong corak kemahiran penaakulan saintifik yang membolehkan murid menjawab dengan betul aspek pengabdian berat dalam kajian ini. Lawson (1995), 3 fasa utama yang berbentuk inkuiri iaitu penerokaan, pengemukaan istilah dan aplikasi konsep adalah penting dalam meningkatkan kemahiran penaakulan saintifik. Pandangan ini turut disokong oleh Bao et al., (2009) dengan menegaskan bahawa kaedah pengajaran guru banyak membantu dalam meningkatkan keupayaan menaakul sains.

Selain itu, berdasarkan kajian didapati bilangan murid yang mendapat 0 (sifar) mata adalah seramai 97 orang mewakili 36.3\%. cBilangan murid yang mendapat skor 1 merupakan jumlah murid yang paling ramai iaitu seramai 102 orang murid $(38.2 \%)$. Bilangan murid yang mendapat skor 2 mata adalah seramai 50 orang murid yang mewakili $18.7 \%$ dan yang mendapat skor 3 mata pula seramai 16 orang yang mewakili $6 \%$ sahaja. Bagi skor 4 mata dan 6 mata hanya seorang murid $(0.4 \%)$ sahaja yang berjaya mendapat jumlah skor yang tersebut.

Pihak Kementerian Pendidikan Malaysia (KPM) perlu memainkan peranan yang lebih agresif dan berkesan bagi memastikan kemahiran penaakulan saintifik dalam kalangan murid dapat dipertingkatkan. Pihak KPM perlu mengadakan lebih banyak bengkel-bengkel dan kursus-kursus yang berkaitan untuk para guru agar guru dapat menerapkan kemahiran penaakulan saintifik dalam kalangan murid-murid mereka. Ini secara tidak langsung akan meningkatkan pencapaian pelajar kita dalam ujian TIMSS dan PISA.

Oleh itu para guru dan pentadbir harus melakukan transformasi untuk memperbaiki amalan pedagogi agar selaras dengan keperluan melahirkan modal insan abad ke-21. Kaedah pengajaran dan pembelajaran yang digunakan oleh guru seharusnya dapat menjadikan suasana tersebut lebih selesa dalam bilik darjah. Murid akan lebih berminat untuk belajar. Pembelajaran yang merangsang motivasi dalaman pelajar akan menjadikannya lebih menyenangkan mereka untuk belajar (Azwan Ahmad, Abd.Rahman Abd. Aziz, Abdul Ghani Abdullah \& Mohammad Zahir Ahmad, 2005).

Kajian TIMSS (KPM, 2001), kaedah pengajaran dan pembelajaran yang berpusatkan guru masih menjadi amalan guru-guru sains dan matematik kini. Pelajar tidak berpeluang untuk membuat penerokaan sendiri melalui kaedah inkuiri penemuan. Pelajar juga tidak diberikan kesempatan untuk membina pengetahuan dan kefahaman secara kontruktivisme. Hal ini berlaku kerana guru masing-masing sibuk untuk menghabiskan sukatan berbanding dengan pembinaan pengetahuan matematik yang sewajarnya (Nik Azis \& Ng, 1991). Aida Suraya (2001) pula menyokong kajian tersebut dengan menyatakan keadaan ini berlaku kerana guru-guru matematik telah dapat meramal format soalan matematik SPM dan menjalankan pengajaran berfokuskan peperiksaan. Nor Azizah Mohd Salleh dan Chong Poh Wan (2000) menyatakan Kementerian Pendidikan Malaysia menyasarkan untuk menyediakan soalan peperiksaan SPM dengan lebih terbuka dengan $60 \%$ soalan melibatkan pemikiran aras tinggi yang menguji kemahiran penaakulan, kemahiran berfikir, kreativiti, sintesis dan berhujah. Ini adalah bertujuan untuk meningkatkan tahap kemahiran berfikir dalam kalangan pelajar.

Aset yang paling penting bagi sesebuah negara adalah rakyatnya. Cabaran yang paling besar adalah bagaimana hendak melahirkan rakyat yang boleh dijadikan sebagai pemikir formal dengan anjakan paradigma supaya menjadi mereka insan sempurna. Ekonomi kini berada dalam era yang berpaksikan ilmu pengetahuan. Sekiranya kita ingin bersaing di persada dunia sebagai negara maju maka kita perlu menyediakan 
bakal-bakal peneraju ekonomi dan negara yang berwawasan tinggi. Usaha perlu digembeleng dari akar umbi bagi melahirkan modal insan yang bermutu tinggi. Penekanan perlu diberikan kepada pembangunan ilmu pengetahuan, penguasaan kemahiran, penerokaan ilmu sains dan teknologi, peningkatan ilmu keusahawanan serta nilai moral dan etika yang tinggi.

Sistem pendidikan negara memainkan peranan yang amat penting bagi membangunkan modal insan bermutu tinggi. Negara amat memerlukan warganegara yang mampu berdaya saing untuk mengharungi cabaran globalisasi dan persaingan ekonomi baru dalam abad ke-21. Oleh itu, sistem pendidikan perlu di transformasi agar berjaya melahirkan rakyat yang berkemahiran tinggi, kreatif, kritis, dan bijak menyelesaikan masalah.

Malaysia sebagai sebuah negara yang sedang mengorak langkah untuk mencapai taraf negara maju berpendapatan tinggi sedang menumpukan segala usaha untuk membina dan membentuk sebuah negara dan rakyat yang menggunakan sains dan matematik sebagai budaya hidup di samping kecanggihan perkembangan teknologi dan inovasi. Masyarakat saintifik yang diharapkan adalah satu masyarakat yang bukan setakat mempunyai kecekapan yang tinggi dalam mengendalikan teknologi terkini malah mempunyai keupayaan serta kemahiran tinggi dalam membangunkan teknologi itu sendiri. Malahan tidak keterlaluan sekiranya kualiti modal insan dijadikan sebagai satu penanda aras bagi mengukur tahap pembangunan sesebuah negara.

\section{RUJUKAN}

Abu Bakar Nordin (1995). Penilaian afektif. Masa Enterprise.

Azwan Ahmad, Abdul Ghani Abdullah, Mohammad Zahir Ahmad dan Abdul Rahman Abdul Aziz. (2005). Kesan Efikasi Kendiri Guru Sejarah Terhadap Amalan Pengajaran Berbantukan Teknologi Maklumat dan Komunikasi ICT. Jurnal Penyelidikan Pendidikan. Jilid 7.

Bahagian Pembangunan Kurikulum. (2012). Dokumen Standard Kurikulum dan Pentaksiran Tahun Empat. Kuala Lumpur: Kementerian Pendidikan Malaysia.

Bao, L., Cai, T., Koenig, K., Fang, K., Han, J., Wang, J., Liu, Q., Ding, L., Cui, L., Luo, Y., Wang,Y., Li, L., Wu, N. (2009). Comparison of Learning And Scientific Reasoning In Chinese \& U.S. Schools: Alternate Conclusions and Recommendations. Learning and Scientific Reasoning, Science. Vol. 323.no. 5914, pp. 586-587.

Kelly, G. J., Carlsen, W. S., \& Cunningham, C. M. (1993). Science education in Sociocultural context: Perspectives from the sociology of science. Science Education, 77(2), 207-220.

Kementerian Pendidikan Malaysia. (2001). Pembangunan Pendidikan 2001-2010. Kuala Lumpur: Kementerian Pelajaran Malaysia.

Kementerian Pelajaran Malaysia. (2012). Laporan Awal Pelan Pembangunan Pendidikan Malaysia 2013-2015. Kuala Lumpur: Kementerian Pelajaran Malaysia.

Lawson, A. E. (1982). Formal Reasoning, Achievemnet and Intelligence: An Issues of Importance. Science Education, 66; 77-83.

Lawson, A. E. (1995). Science teaching and the development of thinking. Belmont, CA: Wadsworth Publishers.

Lawson, A. E. (2000). Revised Edition Based on: Lawson, A.E. 1978. Development and validation of the classroom test of formal reasoning. Journal of Research in Science Teaching, 15(1): 11-24. 
Lawson, A. E., Karplus, R., \& Adi, H. (1978). The acquisition of propositional logic and formal operational schemata during the secondary school years. Journal of Research in Science Teaching, 15(6), 465-478.

Lawson, A. E., Drake, N., Johnson, J., Kwon, Y.-J., \& Scarpone, C. (2000). How good are students at testing alternative explanations of unseen entities? American Biology Teacher, 62(4), 249-255.

Mahathir Mohamad. (1991). Malaysia melangkah ke hadapan. Kuala Lumpur: ISIS \& Dewan Bahasa dan Pustaka.

Mohamad Fadzil (2008). Kesan Kaedah Inkuiri Koperatif Berbantukan Multimedia ke atas Prestasi Kemahiran Proses Sains Bersepadu, Pemikiran Saintifik dan Sikap dalam Sains dalam Kalangan Pelajar-pelajar Sekolah Kebangsaan. Tesis PHD. Universiti Sains Malaysia.

National Research Council (Ed.). (1996). National science education standards. National Academy Press.

Nik Azis Nik Pa \& Ng, S., G.(1991). Laporan tentang pelaksaan KBSM: Fenomena tahun pertama(1989) dan kedua(1990). Laporan dikemukakan kepada Kementerian Sains, Teknologi dan Alam Sekitar.

Nor Azizah Mohd Salleh \& Chong Poh Wan. (2000). A review of cooperative learning research and its implication for teacher education. Proceedings of the International Conference on Teaching and Learning, 24-25 November, pg 1266-1289.

Nor'ain, Nurulhuda Abd Rahman, Noor Shah Saad, Asmayati Yahaya, Hasimah Alimon, Mohd. Uzi Dollah et al., (2011). Kemahiran Penaakulan Saintifik dan Stail Pengajaran Pensyarah: indikasi awal ke arah Peningkatan Kualiti Pengajaran dan Pembelajaran Pelajar Institusi Pengajian Tinggi. Jurnal Pendidikan Sains \& Matematik Malaysia, 3(1), 48-59.

Omar, R., Puteh, Sharifah. N., \& Ikhsan, Z. (1999). Implementation of Science Skills Process in Project Based Learning Through Collaborative Action Research. Proceedings of the International Conference on Educational Reform (ICER 2014), Innovations and Good Practices in Education: Global Perspectives 221-228

Piaget, J., \& Inhelder, B. (1958). The psychology of the child. NY: Basic Books.

Suzana Ayob. (2014). Hubungan antara Kemahiran Penaakulan Saintifik dan Gaya Pembelajaran dengan Pencapaian Matematik Dalam Kalangan Murid Tingkatan Empat. Tesis Master. Universiti Pendidikan Sultan Idris.

Syamsina (2011). Kemahiran Penaakulan Saintifik dan Stail Pengajaran Guru Matematik dan Sains Sekolah Kebangsaan. Tesis Sarjana. Universiti Pendidikan Sultan Idris.

Toffler, A. (1991) Powershift. New York: Bantam Books.

Zimmerman, C. (2007). The development of scientific thinking skills in elementary and middle school. Developmental Review, 27, 172-223.

Zuzovsky, R. \& Tamir, P. (1989). Home and the school contributions to science achievement in elementary schools in Israel. Journal of Research in Science Teaching, 26, 703- 714. 